\title{
USER'S PERCEPTION ON SMALL CAR SEGMENT: A STUDY WITH REFERENCE TO CHENNAI
}

\author{
Stalin R. ${ }^{1}$, Hansa Lysander Manohar ${ }^{2}$, Maran K. ${ }^{3}$ \\ ${ }^{1}$ Research Scholar, Sathyabama University, ${ }^{2}$ St.Mary's School of Management Studies, \\ ${ }^{3}$ Department of Management Studies, Sri Sai Ram Engineering College, Chennai, India \\ E-mail : 'stalinshali@yahoo.com
}

\section{Abstract}

The first motorcar on the streets of India was seen in 1898. Mumbai had its first taxicabs in the early 1900 . After fifty years, cars were imported to satisfy the domestic demands. From 1910 to 1920, the automobile industry made a humble beginning by setting-up assembly plants in Mumbai, Kolkatta and Chennai. The imported/assembly of vehicles grew consistently after 1920's, crossing 30,000 marks in 1930. In 1954, the decision of the Government marked a turning point in the history of the Indian Car Industry. The Govt. of India instructed what type of vehicle each manufacturer should make. Therefore, each product was safety cocooned in its own segment with no fears of any impending competition. In 1985, after the entry of Maruti Udyog, the Car makers were given a free hand to fix the prices of Cars, thus, effectively abolishing all controls relating to the pricing of the end product. The importance of the small car segment emerges from the fact that it serves the common man, middle class of India. The small car has become the most common and become popular. The main objective of the survey is to evaluate users opinion, and also to identify the overall capability of small cars. A note of caution when interpreting these findings, which are based on perception of and opinion of small car owners.

Key words: User's Opinion, Overall Capability, Pricing Controls, Domestic Demands

\section{INTRODUCTION}

The first motor car on the streets of India was seen in 1898. Mumbai had its first taxi cabs in the early 1900. After fifty years, cars were imported to satisfy the domestic demands. From 1910 to 1920 , the automobile industry made a humble beginning by setting-up assembly plants in Mumbai, Kolkatta and Chennai. The imported/assembly of vehicles grew consistently after 1920 's, crossing 30,000 mark in 1930. In 1946, Premier Automobile Ltd. (PAL) earned the distinction of manufacturing the first Car in the country by assembling 'Dodge Desoto' and 'Plymouth' cars in its Kuala plant. Hindustan Motors (HM), which started as a manufacturer of auto components graduated to manufacture Cars in 1949. In 1952, the Govt. of India setup a tariff commission to devise regulations to develop on indigenous automobile industry in the country. After the commission submitted its recommendations, the Government of India asked assembly plants, which did not have plans to setup manufacturing facilities, to shut operations. As a result General motors, Ford and other assemblies closed operations in the country.

In 1954, the decision of the Government marked a turning point in the history of the Indian Car Industry. The Govt. of India instructed what type of vehicle each manufacturer should make. Therefore, each product was safety cocooned in its own segment with no fears of any impending competition. Even though new entrant was not allowed, they had plans of a full-pledged manufacturing program. The restrictive set of policies was chiefly aimed at building an indigenous auto industry. However, the restrictions in foreign collaborations led to limitations on import of technology through technical agreements.
The other control imposed on Car makers was related to the production capacity and distribution. The Government of India control extended even to fixation of prices for Cars and dealers commissions. It triggered the start of protracted legal battle between Car makers and Govt. of India in 1969. In the three till 1980, decades the following establishment of the passenger car industry in India proved to be the 'darkages' for the consumer, as his choice throughout the period was limited to two models viz. Ambassador and Padmini.

\section{THE ERA OF TAKE OFF}

In 1985, after the entry of Maruti Udyog, the Car makers were given a free hand to fix the prices of Cars, thus, effectively abolishing all controls relating to the pricing of the end product. In the early 1980's, a series of liberal policy changes were announced marking another turning point for the automobile industry. The Government of India entered the Car business with 74 percent stake in Maruti Udyog Ltd., (MUL), and the joint venture with Suzuki Motors Ltd., of Japan. In 1985, the GOI announced its famous broad bonding policy which gave new license to broad groups of automotive products like two and fourwheeled vehicles. Though a liberal move, the licensing system was still very much intact.

Maruthi Udayog Limited introduced 'Maruti 800 ' in 1983 providing a complete facelift to the Indian car industry. The Car was launched as a 'Peoples car' with a price tag of Rs.40, 000 . The model changed the industry's profile dramatically. Maruti 800 was well accepted by middle income families in the country and its sales also increased. 
The delicensing of auto industry in 1993 opened the gates to a virtual flood of international auto makers into the country with an idea to tap the large population base on 950 million people. A quantitative restriction on imports by the recent policy is also expected to add up to the flurry of foreign cars into the country.

Many companies have entered the Car manufacturing sector, to tap the middle and premium end of car industry. The new entrants are Daewoo (Matiz), Telco (Indica) and Hyundai (Santro) in upper end of economy Car market. General Motor, Ford, Peugeot, Mitsubishi, Honda and Fiat have entered the mid-sized Car segment and Mercedes Benz is in the Premium end of the market. Car manufacturers like Malaysia based Proton are also in line to hit the Indian ramp.

\section{IMPORTANCE OF THE INDIAN SMALL CAR SEGMENT}

The importance of the small car segment emerges from the fact that it serves the common man, middle class of India. The small car has become the most common and become popular. The segment is very important mode of transportation in India for the following reasons.

2y Small cars are great fun almost as much run as scooter, they are easy to maneuver in crowded city with possibility to take some luggage with you, while you sit dry in case of a shower.

2in Small cars in India are for wide ranging purpose, from being a simple means of conveyance to luggage carriers. They are used as family vehicles carrying four adults and two or three children.

2y They suit the buying capacities of the middle and upper middle classes. Small cars are available in various brands and models suitable for the various pockets and preferences.

2iy Most of the roads in India are narrow, with heavy traffic (especially in cities and without dividers) making congested and totally unorganized. The compactness of small cars makes it possible to move them even through narrow gaps. It is also easy to park them in the available limited space.

2y Small cars help to reduce dependency on the public transport system. Hence traveling time of individuals and their families is reduced enormously and without experiencing tiredness.

29y The sophisticated technology, quality parts and their generally user-friendly applications, make small car easy to handle. The availability of authorised service stations facilitates easy maintenance and best services. Their utility is further enhanced by adding facilities like auto lock systems, power gear, power steering etc.

29 The level of technological advancement has been most rapid and there is cut throat competition in the small car sector when compared with the rest of the automobile industry. The market is being flooded with newer and more fuel efficient vehicles almost as a continuous basis.

29. On an average, the vehicles in all the segments give 15 to $20 \mathrm{kmpl}$. Not surprisingly, with every successive oil price hike, sales of small cars has witnessed largest share.

At the macro level, the small car segment is of interest to academics for the following reasons. According to the ICRA study 2000, small car segment in India, since the liberalisation process started in India, has been instrumental in revolutionising the auto industry and has tremendously accelerated the pace of technological advancement and assimilation.

\section{PROBLEM FOCUS}

In the passenger car segment of the Indian automobile industry identified and introduced small cars as new generation vehicles, and also achieved the highest rate of increase in production and sales between 2000 and 2007.

It could be noted that the market share of small car segment in the overall market of passenger cars in 2000 was 79.78 per cent which decreased to 49.51 per cent in 2003, and again increased to 69.85 per cent in 2007.

Added to this, the changing Indian consumers preference and perception about small cars have to be analysed to examine whether the manufacturers meet the expectations of the consumers. The marketing strategy adopted by the manufacturers of small cars is one of the reasons for the success. An evaluation of their marketing strategy is called for to ascertain whether the market potential for the small car vehicle is fully captured or not. With the prospects forecast for this sub-segment the type of policy support needed by this sub-segment is also to be studied.

\section{A. Objectives}

ow To identify the users satisfaction level through various attributes.

ow To analyze the fulfillment of expectations of users of car.

ow To find out the overall opinion of users about different type of cars. 


\section{REVIEW OF LITERATURE}

Reviews of past studies help any research to define its scope, concepts, working definitions and hypothesis and also formulation of empirical models. Thus, it enhances the knowledge of the researcher and makes his efforts pragmatic and highly productive. Hence a brief review of literature related to the subject of the present study is presented in this chapter. First, earlier works has been discussed. This is followed by a discussion on important developments since 1995 in relation to the small car industry.

Reynolds and Gutman (1984) have identified over sixty attributes that can be ascribed to purchase of automobile, consumers make evaluation based on a limited number of attributes only. According to them, the buyer's evaluation of automobile purchase preference is in the terms of interiors roominess, durability, gasoline economy, warranty coverage and price. Some people compare cars in terms of styling, comfort and performance.

Erickson and Johansson (1985) have investigated the various attributes involved in the purchase of automobile viz., price, horse power, acceleration, mileage, safety driving comfort passenger comfort, reliability workmanship, styling and colour. It was found that price to be loaded highly on quality factor indicates an intervening of price beliefs. with judgment about quality. But the pricing variables are horse power, acceleration and driving comfort.

Patrick Barrett (1997) analysed the company Ford Motors with respect to subject of automobile industry, advertising campaigns, market strategy. Ford had dropped its avant grade TV campaign for 'Ka' its radically shaped small car, in favour of more conventional advertising to boost disappointing sales figure.

According to survey by NOP (1997) solutions, 50 per cent of women were irritated that only car commercials as Nissan Micra and Peugeot 106 targeted for their practical small cars. It was also found that one in three women are more interested in cars. Planning director at GGT observes 56 per cent of men think that cars are more interesting than women. It has been approved by 75 per cent of women.

Yogyata Datta (1997) IIM Bangalore, carried out an detailed study on Automobiles industry analysis. He commenced his study from the Evolution of Automobiles industry in which he framed out into aspects of initial year, 1980s. 1990s and also the future on coming to the discussion about the Global car market, he pointed out various facts, that US has the largest car market in the world, and the second-largest market for cars in the world is Western Europe. In India the correlation between automobile industry and economy growth was low. On coming to the point of market segments, it was analysed that passenger car market in India was divided into following distinct segments as like small car segment, medium car segment, midsize car segment and luxury car segment. From Yogya's discussion about pricing, we can conclude on the following facts related to pricing. Price rise has been mainly due to increased cost of production. The introduction of MODVAT credit has intended to check price and has given a boost to many manufacturers.

\section{METHODOLOGY}

The objective of this study is to analyse the performance of the small car segment of the Indian automobile industry. It required collection and analysis of both primary and secondary data. Secondary data collected are relating to production, sales, prices and other related variables. Primary data are relating to the user preference for the small cars, factors influencing buying decision, users expectations, satisfaction of dealers service etc. This chapter details the design of the study which included methods of selection of manufacturers, sample respondents using small cars, method of data collection, tools for analysis and choice of test statistics. For the reasons stated earlier, the product and manufacturers were selected purposively and they formed the universe of this study.

\section{A. Selection of manufacturers}

The purpose of this study is to analyse the four leading manufacturers in the small car segment, who dominate the market in this category of vehicles selected. The selected manufacturers are Maruti Udyog Limited, Telco Limited, Daewoo Motors India Limited and Hyundai Motor India Limited.

\section{B. Pre-Test}

A pilot study was conducted with an idea of testing the reliability of the questionnaire designed. Samples of 50 car owners from Chennai were selected for this purpose. Based on the views of the respondents the needed modifications are carried out and the questionnaire was standardized.

\section{Sampling Design}

For the study stratified random sampling technique was adopted. Car is a sophisticated and high value product which is usually introduced in metros. Hence among the four metros Chennai was randomly selected. In the next stage among 59 segmnts are Chennai, two were randomly selected. Finally 400 questionnaires were 
distributed among the car owners in the two segments, each area constituting 200. Among the distributed questionnaires, 283 were responded and among that 250 (62.50 per cent) were found to be fit for further analysis which satisfied the required sample size which was calculated based on sampling proportion.

\section{RESULTS AND DISCUSSION}

Table-1. Importance towards Car Attributes

\begin{tabular}{|l|l|c|c|c|c|c|c|c|c|}
\hline Q. & \multicolumn{1}{|c|}{ Attributes } & $\mathbf{5}$ & $\mathbf{4}$ & $\mathbf{3}$ & $\mathbf{2}$ & $\mathbf{1}$ & Total & M & S.D. \\
\hline a. & Price & 79 & 138 & 27 & 4 & 2 & 250 & 4.15 & 0.73 \\
\hline b. & Fuel efficiency & 104 & 126 & 20 & - & - & 250 & 4.33 & 0.62 \\
\hline c. & Speed & 45 & 84 & 88 & 30 & 3 & 250 & 3.56 & 0.96 \\
\hline d. & Size & 43 & 121 & 181 & 5 & - & 250 & 3.80 & 0.73 \\
\hline e. & Style & 49 & 103 & 83 & 12 & 3 & 250 & 3.13 & 0.88 \\
\hline f. & Colour & 66 & 85 & 64 & 34 & 1 & 250 & 3.73 & 1.01 \\
\hline g. & After Sales Service & 113 & 100 & 25 & 12 & - & 250 & 4.25 & 0.83 \\
\hline h. & Less Maintenance cost & 128 & 101 & 15 & 6 & - & 250 & 4.40 & 0.71 \\
\hline i. & Spares availability & 126 & 114 & 9 & 1 & - & 250 & 4.46 & 0.59 \\
\hline j. & Brand Image & 60 & 101 & 72 & 15 & 2 & 250 & 3.80 & 0.90 \\
\hline k. & Durability & 106 & 111 & 29 & 3 & 1 & 250 & 4.28 & 0.75 \\
\hline 1. & Resale value & 71 & 101 & 61 & 16 & 1 & 250 & 3.90 & 0.90 \\
\hline m. & Corporate image & 52 & 70 & 79 & 33 & 16 & 250 & 3.43 & 1.15 \\
\hline n. & Easy fin. provided & 39 & 71 & 62 & 56 & 22 & 250 & 3.19 & 1.20 \\
\hline o. & Exchange offer scheme of comp. & 32 & 61 & 72 & 47 & 38 & 250 & 3.00 & 1.24 \\
\hline p. & Driving comfort & 118 & 107 & 15 & 7 & 3 & 250 & 4.32 & 0.80 \\
\hline q. & Appearance & 60 & 131 & 50 & 9 & - & 250 & 3.96 & 0.77 \\
\hline r. & Sitting Comfort & 106 & 105 & 36 & 3 & - & 250 & 4.25 & 0.74 \\
\hline s. & Safety & 151 & 79 & 13 & 6 & 1 & 250 & 4.50 & 0.74 \\
\hline t. & Trouble-free & 146 & 91 & 7 & 6 & - & 250 & 4.51 & 0.68 \\
\hline u. & Guarantee & 90 & 114 & 35 & 8 & 3 & 250 & 4.12 & 0.85 \\
\hline v. & Social recognition & 45 & 87 & 68 & 42 & 8 & 250 & 3.47 & 1.06 \\
\hline
\end{tabular}

Source: Primary Data

Friedman test value $\quad=\quad 1191.67$

$$
\begin{aligned}
& \mathrm{df}=21 \\
& \mathrm{P}<0.00
\end{aligned}
$$

From the above table the importance was attached to the purchasing factors relating to cars were studied. Twenty two factors were used. In order to know whether they attached equal importance to in the above twenty two factors, Friedman Non-parametric Test was applied. The result implied that importance attached to these factors while purchasing the car significantly different on the above factors. There observed a significant level of difference among these listed attributes at 0.01 level.

In order to know the order of priority attached while purchasing the car Non-parametric Multiple comparison test for Friedman was applied.

It is inferred that first priority in purchasing of car is on the following factors such as safety and trouble free performance.

The users attached second level of importance while purchasing of car were the price, fuel efficiency, after sales service, durability, sitting comfort, guarantee, less maintenance cost, spares availability and driving comfort.

The third levels of preference were towards the factors such as size, style, color, brand image, resale value and appearance of small car.

The forth level of important factors were speed, corporate image and social recognition and the last and the least weightage were given to easy finance and exchange offer facilities.

\section{Table-2. Fulfillment of the Expectations about the attributes}

\begin{tabular}{|c|l|c|c|c|c|c|c|c|}
\hline Q. & \multicolumn{1}{|c|}{ Attributes } & $\mathbf{5}$ & $\mathbf{4}$ & $\mathbf{3}$ & $\mathbf{2}$ & $\mathbf{1}$ & $\mathbf{M}$ & S.D. \\
\hline a. & Price & 53 & 182 & 10 & 2 & 3 & 4.12 & 0.62 \\
\hline b. & Fuel efficiency & 49 & 176 & 25 & - & - & 4.09 & 0.54 \\
\hline c. & Speed & 55 & 165 & 29 & 1 & - & 4.09 & 0.59 \\
\hline d. & Size & 45 & 149 & 47 & 7 & 2 & 3.91 & 0.73 \\
\hline e. & Style & 49 & 149 & 46 & 2 & 4 & 3.94 & 0.75 \\
\hline f. & Colour & 62 & 160 & 23 & 5 & - & 4.11 & 0.64 \\
\hline g. & After Sales Service & 47 & 134 & 46 & 19 & 4 & 3.80 & 0.88 \\
\hline h. & Less Maintenance cost & 39 & 133 & 48 & 26 & 4 & 3.70 & 0.90 \\
\hline i. & Spares availability & 60 & 147 & 32 & 7 & 4 & 4.00 & 0.79 \\
\hline j. & Brand Image & 51 & 147 & 48 & 1 & 3 & 3.96 & 0.72 \\
\hline k. & Durability & 53 & 140 & 42 & 14 & 1 & 3.92 & 0.79 \\
\hline l. & Resale value & 33 & 99 & 92 & 26 & - & 3.55 & 0.84 \\
\hline m. & Corporate image & 38 & 112 & 78 & 17 & 5 & 3.61 & 0.83 \\
\hline n. & Easy fin. Provided & 32 & 109 & 82 & 17 & 10 & 3.54 & 0.83 \\
\hline o. & Exchange offer scheme of comp. & 19 & 78 & 115 & 26 & 12 & 3.26 & 0.94 \\
\hline p. & Driving comfort & 72 & 150 & 24 & 3 & 1 & 4.15 & 0.91 \\
\hline q. & Appearance & 68 & 159 & 15 & 6 & 2 & 4.14 & 0.67 \\
\hline r. & Sitting Comfort & 55 & 145 & 38 & 9 & 3 & 3.96 & 0.69 \\
\hline s. & Safety & 69 & 124 & 42 & 8 & 7 & 3.96 & 0.79 \\
\hline t. & Trouble-free & 62 & 134 & 39 & 15 & - & 3.97 & 0.90 \\
\hline u. & Guarantee & 43 & 133 & 60 & 14 & - & 3.82 & 0.80 \\
\hline v. & Social recognition & 46 & 134 & 63 & 7 & - & 3.87 & 0.73 \\
\hline
\end{tabular}

Source: Primary Data

Friedman test value $\quad=\quad 620.02$

$$
\mathrm{df}=21
$$

From the mean value, it could be observed that all the attributes were normally satisfactory. To identify whether there is any significant level of difference among the expectation fulfillment levels on various factors, Friedman Non-Parametric Test was level. It was found that the fulfillment of the expectation level was significantly different for various factors. In order to know the order of fulfillment Multiple Comparison Test for Friedman Test was applied. The fulfillment of the expectations was highly satisfied on the following factors such as price, fuel efficiency, speed, color, spares availability, driving comfort, exchange offer scheme, with sitting comfort, safety and trouble free performance of engine. 
The following factors of small car, the users fulfillment of expectations are of the second level to the factors, such as size, style, brand image, durability, social recognition and guarantee. The third level of fulfillment of the expectation was found for the factors sales service and less maintenance cost. They experienced cost fulfillment of the expectations for the following factors such as resale value, corporate image and easy finance provided by the company.

\section{Table-3. Satisfaction Level of Product Attributes}

\begin{tabular}{|c|c|c|c|c|c|c|c|c|c|c|c|c|}
\hline \multirow{2}{*}{$\begin{array}{l}\text { S. } \\
\text { No. }\end{array}$} & \multirow[t]{2}{*}{ Capability } & \multicolumn{2}{|c|}{ Maruti } & \multicolumn{2}{|c|}{ Telco } & \multicolumn{2}{|c|}{ Santro } & \multicolumn{2}{|c|}{ Matiz } & \multirow{2}{*}{$\begin{array}{c}\text { Kruskal } \\
\text { Wallis }\end{array}$} & \multirow{2}{*}{$\begin{array}{c}\text { P. } \\
\text { Value }\end{array}$} & \multirow{2}{*}{$\begin{array}{c}\text { Non para } \\
\text { Multiple } \\
\text { comparison test } \\
\text { result }\end{array}$} \\
\hline & & Mean & S.D & Mean & S.D & Mean & S.D & Mean & S.D. & & & \\
\hline a & Road Grip & 4.15 & 0.59 & 4.27 & 0.45 & 4.47 & 0.50 & 4.26 & 0.54 & 11.23 & 0.11 (S) & $1 \mathrm{v} 3,2 \sqrt{3}, 43 \mathrm{v} 4$ \\
\hline b. & Power Steering & 3.77 & 0.84 & 4.50 & 0.57 & 4.38 & 0.90 & 4.11 & 0.67 & 38.41 & 80.011 (S) & Iv2, $4,2 \times 4,3 \times 4$ \\
\hline \multirow[t]{2}{*}{ c. } & Seat Position & 3.80 & 0.72 & 4.26 & 0.44 & 4.42 & 0.61 & 4.14 & 0.68 & 32.62 & $0.001(\mathrm{~S})$ & $1 \sqrt{2}, 3,4,2 \sqrt{3}, 4$ \\
\hline & & & & & & & & & & & & $3 v 4$ \\
\hline d. & $\begin{array}{l}\begin{array}{l}\text { Negotiating } \\
\text { Pot holes }\end{array} \\
\end{array}$ & 3.65 & 0.91 & 3.90 & 0.75 & 3.85 & 0.81 & 3.59 & 0.70 & 3.87 & $0.275(\mathrm{NS})$ & . \\
\hline e. & $\begin{array}{l}\text { Negnotiating } \\
\text { Heavy traffic }\end{array}$ & 3.97 & 0.69 & 3.93 & 0.98 & 4.12 & 0.52 & 3.85 & 0.71 & 3.69 & $0.296(\mathrm{NS})$ & - \\
\hline f. & Braking Power & 4.01 & 0.63 & 4.30 & 0.53 & 4.28 & 0.67 & 4.16 & 0.62 & 14.82 & .002 (S) & $1 \mathrm{v} 2,4,2 \mathrm{v}, 3 \mathrm{v} 4$ \\
\hline $\mathrm{g}$ & Taking Bumps & 3.39 & 0.94 & 3.80 & 0.80 & 3.75 & 0.84 & 3.54 & 0.77 & 8.42 & $.038(\mathrm{~S})$ & Iv2,4,2v4,3v4 \\
\hline h. & $\begin{array}{l}\text { Stability on } \\
\text { ommering }\end{array}$ & 3.80 & 0.67 & 4.000 & 0.91 & 4.00 & 0.54 & 3.76 & 0.82 & 6.11 & 0.106 (NS) & . \\
\hline i. & $\begin{array}{l}\begin{array}{l}\text { Passenger } \\
\text { comfort }\end{array} \\
\end{array}$ & 3.75 & 0.78 & 4.23 & 0.43 & 4.24 & $0.60 \mid$ & 4.09 & 0.76 & 22.16 & $60.001(\mathrm{~S})$ & $1 \sqrt{2,4}$ \\
\hline j. & Driver Safety & 3.96 & 0.69 & 4.20 & 0.55 & 4.24 & 0.63 & 4.14 & 0.64 & 7.68 & $0.063(\mathrm{NS})$ & . \\
\hline
\end{tabular}

* Significant

** Not significant

Satisfaction levels of car attirubtes were tabulated. Further attempt was made to study whether there is any significant difference relating to different attributes among the different car owners. For this purpose to find out any significant difference, Non-Parametric Multiple Comparison Test was used. There is no significant difference exists among the different brand owners relating to the factors such as negotiating pot holes, negotiating heavy traffic, stability on cornering and driver safety. All the small car owners have experienced similar satisfaction level relating to the above factors.

Regarding the factors, such as Road grip, Power Steering, Seat Position, Braking Power, Taking Bumps, and Passenger comfort, the satisfaction level was found to vary significantly among the different types of car owners.

Though the satisfaction level on Road grip is satisfactory for all types of car owners. The result indicates that the Maruti car owners are slightly less satisfied when it is compared to Santro car owners. Matiz and Telco car owners are also slightly less satisfied when it is compared to Santro car owners. Road Grip is found to be the best in Santro car.
Power steering, one of the features of small car, among the different comparing the car owners it was observed. Maruti car owners are are less satisfied when it is compared to Santro car owners and at the same time, there is no difference in satisfaction level between the Indica and Santro car owners. Further, Santro car owners are highly satisfied when it is compared to Matiz car owners. The Matiz car owners are slightly less satisfied when it is compared to Indica car owners. When the Santro car owners' satisfaction level is compared with Matiz car owners, the Santro car owners are fully satisfied other than Matiz car owners.

The satisfaction level of different car owners in comfort seat position is to drive and to have comfort journey. Overall, seat position is fully satisfied by all types of car owners. Among the satisfaction level, to identify whether there is any significant difference, Kruskal Wallis Test was applied for result. The result indicated that the satisfaction level of different car owners varied significantly. The Maruti car owners are less satisfied when compared to Indica car owners; the Indica car owners are slightly less satisfied. In the satisfaction level, the Santro car owners are more satisfied than the Matiz car owners.

The overall Braking power is satisfactory for all types of car owners. The Maruti car owners are the least satisfied customers compared with all other car owners. The result indicated that Maruti car owners are less satisfied when compared to Indica car owners. At the same time, the Matiz car owners braking power satisfaction level is slightly less satisfied when compared to Indica car owners. The Indica and Santro car owner satisfaction level do not vary significantly. Indica car is found to be good relating to the attribute 'Braking Power'.

The overall satisfaction level of different car owners relating to 'taking bumps' and pickup are less satisfactory. The Maruti car owners are not fully satisfied when it is compared to Indica car owners. Though the general satisfaction level is less satisfactory. The comparison indicated that Indica car owners satisfaction level is more satisfied than Matiz car owners. The Matiz car owners are slightly less satisfied and there is no significant difference between Indica and Santro car owners and finally the Matiz car owners satisfaction level is also slightly less satisfied when it is compared to Santro car owners.

Overall passenger comfort was satisfactory for all types of car owners. Among the satisfaction level, to identify whether there is any significant difference, Kruskal Wallis Test was applied for finding out the significant difference. The result indicated that the Maruti car owners are very less satisfied when they are compared to Matiz car owners and the Matiz car owners are slightly less 
satisfied when compared to Indica car owners. There is no significant difference between Indica and Santro car owners.

Table-4. Opinion about the Overall Capability of Different Type of Cars

\begin{tabular}{|c|c|c|c|c|c|c|}
\hline Type & $\begin{array}{c}\text { No. of } \\
\text { Respondents }\end{array}$ & $\begin{array}{c}\text { Capability } \\
\text { Mean Rank }\end{array}$ & Mean & S.D. & Minimum & Maximum \\
\hline Maruti & 129 & 107.30 & 38.28 & 5.15 & 29 & 50 \\
\hline Telco & 30 & 149.83 & 41.40 & 4.49 & 35 & 50 \\
\hline Hyundai & 49 & 162.13 & 41.89 & 4.49 & 33 & 50 \\
\hline Daewoo & 42 & 121.29 & 39.69 & 5.03 & 31 & 50 \\
\hline
\end{tabular}

Source: Primary Data

$$
\begin{array}{rll}
\text { Chi-square } & = & 24.462 \\
\text { df } & =3 \\
\mathrm{P} & = & <0.001
\end{array}
$$

The above table reveals the opinion about the overall capability of different type of cars. In order to know whether there is difference in capability of different types of car, Multiple Comparison Test for Kurskal Wallis Test has been applied. The result indicated that there is variation of different car capabilities.

Overall score is 50 , out of 50 the average score of Maruti is is 38.28 , i.e., 76.4 percent (i.e. $38 / 50 \times 100=$ $76.4 \%$ ). Similarly for Telco, it is 82.8 percent, Hyundai it is 83.6 per cent and for Matiz, it is 79.2 per cent. Maruti car was found to be least in performance but the sales is very high. On the other hand Matiz car sales are very low, even though the car performance is highly perceived. Finally the sales both Telco and Hyundai car is tremendously increasing in their sales and market share and their performance of the two brands which were perceived high and possessed number one position in capability.

\section{CONCLUSION}

A note of caution when interpreting these findings, which are purely based on users satisfaction and expectations of small cars. First of all the importance of various attributes while purchasing of car are safety and trouble free performance. The users attached second level of importance while purchasing of car were the price, fuel efficiency, after sales service, durability, sitting comfort, guarantee, less maintenance cost, spares availability and driving comfort. The second analysis is the fulfillment of expectations about the attributes related to car owners, the fulfillment of expectations were highly satisfied such as efficiency, fuel, price, speed, spares available, driving comfort, colour etc., The third analysis related to these satisfaction level relating to various car attributes such as road grip, power steering, seat position, braking power, taking bumps, and passenger comfort, the satisfaction level was found to vary significantly among the different types of car owners. Finally from the survey, the overall opinion of car owners regarding the capability of different cars, Santro and Indica car owner's perception are similar. The second level of opinion of owners regarding the capability of car to Maruti even though the car is number one market share in Indian car market in the last 20 years and third opinion to Matiz.

\section{REFERENCES}

[1] Aaker David.,A. \& Day George S. Marketing Research, 4 edn. [John Wiley \& Sons, New York] 1990

[2] Anderson Janathan, Durston Berry H., \& Poole Millicent Thesis and Assignment writing 1 edn. [Wiley Eastern Ltd., New Delhi] 1992

[3] Anonymnous, "JD Power releases new ranking", Marketing News, Nov, 1995, P.3.

[4] Anonymous, "Prospects for the Automotive Import Sector", Japanese Motor Business, 1995, P.115-127.

[5] Anonymous, "Small cars high hopes", Times New york, 1994, P.58.

[6] AP Gandhi. The Hindu, Survey of Indian Industry, 1999. P.294

[7] Aron, "Reallymean", Solan Management, Rev. Vol.26, 1986, P.

[8] Baronson Jack, Automotive Industries in Developing Countries, [John Hopkins press, Maryland' 1989

[9] Black James, A., \& Champion Dean, J., Methods and issues in Social Research [John Wiley \& Sons Inc., New York] 1976

[10] Bond and Cashy, "Sounding out incentives", Marketing, Jan 14, 1995, P.18.

[11] Bovee Courtland L., Houston Michael, J., and Thill John., V.,Marketing 2 edn. [Mc Graw Hill Inc. USA] 1995

[12] Brown Leland, Effective Business Report writing 3 edn. [Prentice Hall Inc., New Jersey] 1973

[13] Chandra Prassana, Finance sense, an easy guide for non-finance executives [Tata McGraw Hill Publishing Company Ltd., New Delhi] 1993 
[14] Chandralekha, "Fuel for the future", Business Mandate, Jan. 2002, P.12.

[15] Cravens David, W., Hills Gerald, E. \& Woodruff Robert, B., Marketing Management [Richard D. Irwin Inc. Illinois] [All India Traveller Bookseller, New Delhi] 1988

[16] Enis Ben, M., Core Keith, K, Aaker David.,A. \& Day George S.,Marketing Classics - A selection of Influential articles, 5 edn. [Allyn \& Bacon Inc., USA] 1985

[17] Erickson and Johansson, "Role of Pricein in Multi Attribute Product Evaluations", Jl. Con. Res (Vol) 12, 1985, 446-462.

[18] Field and Graham, "On the Road to a Travel Bonanza", Euramaney, 1994, P.67.

[19] Gandhi, J.C., Marketing - A Managerial Introduction [Tata Mc Graw Hill Publishing Co. Ltd., New Delhi] 1993

[20] Georgepaker, "MC Technology", Marketing Intelligence, 1998, P.20.

[21] Halstead, "Product warranty and post purchase service-A model of consumer satisfaction with complaint resolution", 1995, P.

[22] Jean Halliday, "Chairman Ford Plays to $\mathrm{Tr}$ audience", Advertising Age, Apr. 2002, P.4-6.

[23] Jean Halliday, "Young Buyers Increasingly Critical", Advertising Age, Apr. 2002, P.10.

[24] Jean Hallidry, "Campaign under drivers to say hells to new Neon", Advertising age, Nov. 1999, P.8.

[25] Jeff Green, "Small cars are surging", Brandweek, May 15, 2000, P.16-18.

[26] K.Maran \& Dr.S.Madhavi, "Technology Management in Automotive Industry, Business Mandate, Jan. 2002, P.3.

[27] K.Maran and S. Madhavi, Technology Management in Automobile India, The Mandate, Jan. 2002. P.4.

[28] K.Maran, "Scenario of car Industry in India", Motor India, (Hindi Edition) Jan. 2002, P.38

[29] Keown Arthur, J., Martin John, D., Scott David, F. \& Pretty J. William, Basic Financial Management 3 edn [Prentice Hall of India Pvt. Ltd. New Delhi] 1986
[30] Kotler Philip Marketing Management - analysis planning, implementation and control 6 \& 8 edns. [Prentice Hall of India Pvt. Ltd. New Delhi] 1989, 1995

[31] Kress George, Marketing Research 3 edn. [Prentice Hall of International Inc. USA] 1988

[32] Kumar, "3+3 mantras for sustainable competitive advantage", Business Mandate, Jan. 2002, P.12.

[33] Kurtz David, L., Boone Louise, E., Marketing [The Dryden Press, a division of Holt, Rinehart and Winston, USA] 1981

[34] Leem Thomas, "Automobile Industry on the upswing", The Hindu, 1999, P.11.

[35] Leland Teascher, "The long and short of wide tires", Marketing, 2000, P.108.

[36] Majumdar Ramanuj,Product Management in India [Prentice Hall of India Pvt. Ltd., New Delhi] 1993

[37] Mathew, M.J., Business and Government [RBSA Publishers, Jaipur] 1993

[38] Mr.Maran \& Madhavi, "Passenger cars enormous scope for development", Motor India, Aug. 2002, P.92.

[39] Narayanan, D., The Motor Vehicle Industry in India [Centre for Development Studies, Trivandrum, Oxford \& IBH Publishing Co. Ltd., New Delhi] 1989

[40] Nickmaling, "Driving ambition", Marketing week, 1999, P.26-29.

[41] Nickmaling, "Sastchiwins Ltom Yaris Launch", Marketing Week, 1998, P.10.

[42] Pandey, I.M. , Financial Management [Vikas Publishing House Pvt. Ltd., New Delhi] 1995

[43] Parick Barrett, "Who's in the Drung Seat", Marketing, 1997, P.8.

[44] Patrick Barett, "Ford to Reshape Surreations", Marketing, 1997, P.1.

[45] Pitchard and Barry, "Brand of the week", Marketing, 1993, P.11.

[46] Proctoro Tony, Marketing Management Integrating Theory and practice [International Thomson Business Press, London] 1996

[47] Ramaswamy V.S. \& Namakumari, S., Marketing Management - Planning, Implementation \& Control The Indian Context, 2 edn. 1995 
[48] Reetha Dinesh, "Automobile Industry on overview", Business Mandate, Jan. 2002, P.7.

[49] Reynolds and Gutman, "Advertising is Image Management", Advertising Vol.24, 1984, P.27-36.

[50] Salvatore S. Dominick,Managerial Economics [Mc Graw Hill book Co., USA] 1989

[51] Schiffman Leon, G. Kanuk Leslie Lazer,Consumer Behaviour 3 edn. [Prentice Hall Inc. New Jersey] 1987

[52] Sengupta Subroto, Brand Positioning Strategies for Competitive advantage [Tata Mc Graw Hill Publishing Co. Ltd., New Delhi] 1991

[53] Sharma, D.D., Marketing Research - Principles applications \& Cases [Sultan chand \& Sons, New Delhi] 1996

[54] Stanton William, J. Etzel Michael, J. \& Walker Bruce, J.,Fundamentals of Marketing, 10 edn [Mc Graw Hill Inc. USA] 1994
[55] Sullwar and Tom, "Acquisition and Merges", Marketing weak, Feb 4 1994, P.20.

[56] Vincent Considine, Reserach Director, MIRA, "Planning the future technology", Motor India, Aug. 2002, P.71.

[57] Walker and Jo-Anne, "Big squeeze", Marketing week, 1996, P.41..

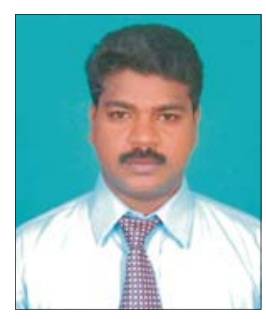

Mr. R. Stalin - Project and Research Assistant, Sathyabama University. He has 5 years of academic research experience. He has presented 3 papers in national and international conferences. His areas of interest are Consumer Behaviour and Customer Relationship Management. 